Moral Disengagement and Building Resilience to Violent Extremism: An Education Intervention

Anne Aly

Department of Social Sciences and International Studies, Faculty of Humanities

Curtin University, Perth, Australia

Elisabeth Taylor

School of Education

Curtin University, Perth, Australia

Saul Karnovsky

School of Education

Curtin University, Perth, Australia

Please send all correspondence to anne.aly@curtin.edu.au 


\section{Building Resilience to Violent Extremism: An Education Intervention}

\section{Abstract}

This article reports on the development and development of an education intervention, the Beyond Bali Education Resource ${ }^{1}$ that applies a conceptual framework grounded in moral disengagement theory. Beyond Bali is a five module program for schools that is specifically designed to build social cognitive resilience to violent extremism by engaging self-sanctions and preparing students to challenge the influence of violent extremism that can lead to moral disengagement. The theory of moral disengagement has been applied to the study of radicalisation to violent extremism to explain how individuals can cognitively reconstruct the moral value of violence and carry out inhumane acts. The mechanisms of moral disengagement through which individuals justify violence, dehumanise victims, disregard the harmful consequences of violence and absolve themselves of blame have been used in the construction of violent extremist narratives. However, they have not been applied to the development of intervention strategies that aim to counter the radicalising influences of violent extremist narratives.

\section{Introduction}

Education interventions have been developed as preventative programs targeting gang behaviour, gun activity and other forms of anti-social behaviour among young people. To date, the application of education interventions in the prevention of violent extremism has not been fully developed, though it has had some consideration in the literature on building resilience to violent extremism. Education, particularly of young people, is recognised as an important and vital component of a comprehensive countering violent extremism approach particularly in the context of building cognitive capacity to resist violent extremist messages. Current evidence suggests that most efforts to develop education interventions for the prevention of violent extremism in schools tend to focus on promoting tolerance and understanding through citizenship education and the teaching of civic values. In Australia, some attempts to teach high school students about terrorism have met with community and public outrage, primarily due to the approach taken to discussing terrorism in the classroom context. In one example, a government high school in Western Australia came under attack for setting students an assignment to plan a terrorist attack in order to engage them in how beliefs and values influence behaviours. ${ }^{2}$ The case drew national and international media attention and highlighted the ethical and methodological challenges to teaching about terrorism to support critical understandings of violence amongst adolescent learners. Beyond the classroom context, Weine and Ahmed, for example, identify opportunities for civic engagement and the provision of supervised after-school activities as strategies to diminish opportunities for violent extremism among Somali-American youth in Minneapolis. ${ }^{3}$ Education programs also appear in de-radicalisation strategies in the form of religious re-education.

This paper reports on the development and implementation of Australia's first education intervention designed to educate adolescent learners about terrorism and build cognitive resilience to violent extremism. The Beyond Bali Education Program (Beyond Bali) is a five module program aimed at 15/16 year olds that consist of five learning modules. Progressively, the modules build social cognitive resilience to violent extremism by preparing students to challenge the influence of violent extremism that can lead to moral disengagement. Beyond Bali is grounded in theories of moral disengagement and moral development which together offer a conceptual framework and 
pedagogic approach for the development of education intervention that can equip students with the capacity to engage their self sanctions and respond in positive ways to terroristic narratives that challenge their moral engagement. The program was piloted in 2012 and is currently being distributed to government and private schools throughout Australia.

The paper is divided into four sections. The first examines current educational approaches to building resilience to violent extremism primarily through programs that integrate teaching civic values, democratic participation and social harmony. This section attempts to build an argument for the application of a moral disengagement framework and moral education for informing education interventions to counter violent extremism. The second section explores the concepts of risk, vulnerability and resilience in the context of education interventions to violent extremism. Overall, the literature in both areas covered in these sections is scant and underdeveloped. Much of the literature on vulnerability and resilience to violent extremism draws on other forms of violence such as gang activity and youth crime. Similarly a review of the literature on teaching methods that help to build resilience to extremism yielded no empirical studies or case studies specific to violent extremism. In this context, the third section attempts to construct the conceptual framework for an education intervention to counter violent extremism. At the heart of this section is a call to examine how social-cognitive mechanisms of moral disengagement that have been used as organising principles for understanding radicalisation, can also be applied to preventative measures. While measures of moral disengagement processes have been used to predict acts of violence and support for violent extremism among young people, the same level of attention has not been given to examining how preventative interventions may enhance personal resilience to radicalising influences through the activation of self-sanctioning mechanisms that can potentially psychologically immunise young people against the social influences of moral disengagement. The final section presents the Beyond Bali education program and explains how moral disengagement theory and moral education pedagogical approaches form the basis for the theoretical constructs upon which the program was developed. This section begins with a discussion on the local context with a focus on Australian response to the Bali bombings in October 2002 that claimed 202 lives, including 88 Australians. This is followed by a description of the program highlighting how cognitive behavioural and knowledge based modes of teaching and learning were integrated into the program to modulate moral disengagement mechanisms and reinforce self-regulatory mechanisms in the learners. The results of the initial pilot and evaluation of the program are also reported in this paper, though it should be noted these results are not presented as a substantive evaluation of the program.

\section{Educational approaches to building resilience to violent extremism}

Education plays a preeminent role in the socialisation of young people and their moral development. Consequently, education features strongly in the counter-radicalisation programmes of some States. For the most part, education interventions focus on the teaching in schools of subjects that promote tolerance, understanding and citizenship. The United Kingdom's Prevent Strategy has produced a variety of activities in schools in recognition of the fact that schools play a vital role in preparing young people to challenge violent extremist influences. These efforts have primarily focussed on "developing a positive and inclusive ethos that championed democratic values and human rights" 4 . Compulsory school curricula in Austria, the Netherlands, Belgium and Australia include citizenship education, civic values and cultural diversity. These programs are valuable in their own right, but reflect some of the problems of the broader policy approach to preventing violent extremism and 
building resilience that assume that violent extremism can be prevented by developing democratic participation.

Policies and programs to counter terrorism and violent extremism place particular emphasis on youth at risk of committing violent crimes influenced by ideology. This has been most pronounced in the preventative components of national counter terrorism strategies that predominantly target youth perceived to be at risk of ideological influences that promote the use of violence. In Australia, for example, the Resilience strand of the Australia's counter terrorism approach has largely focussed on providing funding for programs that target Muslim youth. A large proportion of funding has been allocated to programs that aim to promote democratic participation of young Muslims; address issues of alienation and marginalisation; foster young Muslim leaders and enhance Muslim youth civic competencies.

While the popular assumption is that a lack of opportunity for democratic participation is a root cause of violent extremism because violence is seen to be a last resort tool of the politically oppressed, the literature is inconclusive. In relation to the lack of democratic participation of diaspora Muslim youth, the consensus in the literature is that there is no relationship between religion and participation. A study on the relationship between religiosity and civic participation among Muslim and Christian youth in the Netherlands found that, despite popular assumptions that Muslim youth are disassociated from democratic institutions both Muslim and Christian adolescents have more developed democratic competencies than their non-religious counterparts ${ }^{5}$. These findings are echoed by Attar-Schwartz and Ben-Arieh whose study on political attitudes and knowledge among Palestinian and Jewish youth concluded that political involvement was higher among more religious youth, both Jewish and $\mathrm{Arab}^{6}$. Similarly, research on the political participation of ethnic minority youth in Belgium revealed that while they do have lower levels of political participation, participation was influenced not by citizenship status or religion but by gender, socioeconomic status, language attributes and group identity ${ }^{7}$. These studies indicate that programs targeting Muslim youth political participation and democratic engagement are more likely to be effective if they also take into account the broader social and economic conditions of Muslims in the diaspora.

Programs that aim at preventing violent extremism are better placed focussing on the kinds and forms of political participation available to Muslim youth. In an environment where Muslims have been excluded from participation in the public sphere, Australian Muslims are turning to alternative modes of political participation and finding new ways of engaging in political debates about their citizenship rights ${ }^{8}$. A similar phenomenon can be observed among young British Muslims who respond to perceived discrimination in political and media discourses in creative ways that offer alternatives to those conventional forms of mainstream politics ${ }^{9}$. The arguments made by these authors lend some legitimacy to programs that provide Muslim youth with positive avenues for expressing political dissent but do not comprehensively explain the exclusive focus on Muslims or the contribution that such programs can make to aim of countering violent extremism.

A report on the United Kingdom's approach to preventing violent extremism by the Communities and Local Government Committee concluded that the single focus on Muslims has been counterproductive to the aims of Prevent and called for a refocus of Prevent to address a broader range of extremism across all communities and dependent on a more comprehensive and effective 
assessment of risk ${ }^{10}$. Criticisms of Prevent also raise questions about the cost effectiveness of government funded counter terrorism initiatives that target specific communities assumed to be vulnerable(namely Muslim), are premised on the marginalisation hypothesis, give primacy to the role of religion focus narrowly on radicalisation ${ }^{11}$.

Progressive iterations of Prevent have attempted to address some of the issues identified by evaluations and criticisms of the strategy. At the same time, however, countering violent extremism efforts continue to be driven by a single focus on individual and/ or group vulnerability to extremist violence while grappling with or completely ignoring the broader psycho social factors associated with the phenomenon.

In light of the arguments levelled against preventative responses to terrorism, targeted educational interventions that build personal resilience by developing the self-regulatory function of young people may be effective in immunising young people against the ideological influences of violent extremism. It is in this sense that the social cognitive theory of moral disengagement can contribute to the development of educational interventions for violent extremism.

Applications of the theory of moral disengagement and engagement to the study of terrorism and violent extremism are not new ${ }^{12}$. However, a moral disengagement framework for informing interventions to counter violent extremism has not been fully developed. Pels and de Ruyter theorise that moral education can prevent radicalisation by countering signs of moral disengagement and reinforcing faithfulness to moral standards. Their analysis of theoretical and empirical studies about parental and education contexts in relation to radicalisation found a need for educational practices and programs that target radicalisation. Pels and de Ruyter conclude that "current practices in schooling often do not seem apt to diminish the susceptibility to radicalization in youngsters"13.

A rapid evidence assessment of teaching methods that help to build resilience to extremism conducted a review of the literature in relation to preventative programs targeting gangs and gun activity and violent extremism among young people. As expected, the review found no empirical studies or case studies on educational approaches to preventing violent extremism with the exception of Boucek's description of Saudi-Arabia's counter terrorism strategy which includes an education program run by the Ministry of Education to raise awareness of the dangers of extremism and the negative impacts of terrorism and violent extremism ${ }^{14}$.

The review identified seven types of preventative initiatives:

- Cognitive behavioural initiatives- such as anger management, empathy, problem solving, moral reasoning and mindfulness strategies;

- Mentoring and counselling approaches- primarily targeting young offenders;

- Knowledge based initiatives- programmes that aim to change attitudes and behaviours by educating young people about the consequences of gangs, guns and knife crime and antiracist education and awareness raising;

- Peer mediation and conflict resolution approaches- based on social cognitive theory to instruct students how to express anger without resorting to violence;

- Family based approaches- parent and carer training in child behaviour management;

- Community based approaches- such as outreach work and after-school programs; 
- Opportunity provision - providing young people with educational and employment opportunities $^{15}$

Educational approaches tend to focus primarily on targeting youth identified as being at risk of gang involvement and crime. While such programs do not specifically address violent extremism, they do provide some good practice guidelines including taking an evidence based approach, working collaboratively and involving cooperation from school personnel.

\section{Risk, vulnerability and resilience}

Resilience is a concept most commonly used in the fields of psychology and public health to refer to an individual's or community's capacity to achieve successful outcomes in the face of adversity. Studies on resilience define a particular risk or challenge and measure positive or successful adaptations to that challenge ${ }^{16}$. Studies on child and adolescent resilience reveal certain characteristics or traits that make some adolescents immune to harsh or disadvantageous environmental influences. They also identify protective factors that enhance adolescents' capacity to deal with adverse experiences ${ }^{17}$.

Research into child and adolescent risk and resilience tends to focus primarily on risk factors for problems such as alcohol abuse, delinquency and gang violence. There is little research available on adolescent risk and resilience in regard to violent extremism, though resilience is often cited as a central consideration in the development of countering violent extremism approaches. Several studies on adolescent risk and resilience confirm that adolescents are highly vulnerable to ideological influences. Adolescence is a period of intense psychosocial development characterised by a search for ontological security and consolidation of ideological identity. One study by Laor et al evaluated symptoms, risk and protective factors of Israeli adolescents continuously exposed to terrorism and violence. The study found that perceived personal resilience was a significant protective factor against negative symptoms. Laor et al conclude that early interventions to build personal resilience may help protect against the negative symptoms of exposure to terrorism and violence ${ }^{18}$.

One specific study by the National Consortium for the Study of Terrorism and Responses to Terrorism (START) on resilience to violent extremism among Somali Americans affirms that there is no single risk factor for involvement in violent extremism. Rather multiple risk factors interact at the family, peer, community, global, state and social levels. The combination of risk factors operate to create three levels of opportunity for involvement in violent extremism: "youth's unaccountable times and unobserved spaces; the perceived social legitimacy of violent extremism and contact with recruiters or associates" ${ }^{19}$.The study does not identify protective factors but calls for a focus on strengthening protective resources and reducing opportunities for involvement.

A rapid evidence assessment of vulnerability and resilience to Al-Qaida violent extremism and other types of violent activity (animal rights activism; cults; gangs; right wing extremism and youth crime) prepared for the Office of Security and Counter-Terrorism concluded that the evidence on risk and resilience factors for violent extremism is lacking ${ }^{20}$. Based on limited empirical evidence the report concludes that there is no specific risk or vulnerability profile for $A Q$ influenced violent extremism. It identifies social, psychological, and physical risk factors. Social risk factors include broad demographic characteristics- male, young to middle-aged, married and possibly with children- there 
was no identifiable discrepancy between the education levels or socio-economic status of $A Q$ influenced violent extremists and the broader community though there was some suggestion that they may be working at lower skill levels than their educational attainment.

Psychological risk factors were also difficult to identify with religion playing a far lesser role in vulnerability than political ideology or grievance. Physical risk factors include support and reinforcement from family and peers, interpersonal bonds, social settings and spaces that provide opportunities for involvement and recruitment. Social and psychological risk factors identified in other, non- Al-Qaida influenced, forms of violent extremism included family stability, educational attainment, personality or psychiatric problems, drug and alcohol abuse and previous criminal convictions.

As mentioned, the study found scant evidence on the resilience factors for $A Q$ and other forms of violent extremism. Resilience factors identified by the study included educational attainment, awareness and tolerance of other religious and ethnic groups and financial stability ${ }^{21}$.

\section{Moral Disengagement and Violent Extremism}

In the social cognitive theory of moral disengagement, moral agency is expressed both as a refrain from behaving inhumanely and in proactively behaving humanely. The theory of moral disengagement suggests that individuals engage in violence and aggression in violation of their own moral standards. These moral standards are adopted through the course of socialization and serve as guiding principles for moral conduct. Behaviours that conflict with an individual's moral standards create high levels of discomfort and hence are avoided through self -sanctions. Conversely, behaviours consistent with moral values create high levels of self-worth and hence are activated through positive self-sanctions ${ }^{22}$. When faced with situations and influences that contradict their moral standards of right and wrong, people can choose to behave morally by exerting self-influence.

Individuals who are otherwise socialised can commit acts of violence with no sense of self-censure and do so through a gradual process of disengagement. Moral disengagement is a psychological process through which self- regulatory mechanisms of internal control are disengaged or dismissed. Self-sanctions are disengaged through the mechanisms of moral disengagement: "reconstruing conduct as serving moral purposes, obscuring personal agency in detrimental activities, disregarding or misrepresenting the injurious consequences of one's actions, and blaming and dehumanizing the victims ${ }^{23}$ Collectively, the mechanisms of disengagement allow individuals to cognitively reconstruct the moral value of violence, putting aside self-sanctions, so that acts of violence can be committed. According to Bandura, violent extremism can be explained as such:

The conversion of socialized people into dedicated combatants is achieved not by altering their personality structures, aggressive drives, or moral standards. Rather, it is accomplished by cognitively restructuring the moral value of killing, so that it can be done free from selfcensuring restraints ${ }^{24}$

The majority of research on moral disengagement in the field of terrorism studies examines extremist narratives in relation to the mechanisms of moral disengagement. A study by Hafez of the last will and testament video speeches made by Palestinian suicide bombers drew linkages between the content of these media products and mechanisms of moral disengagement. In Hafez's study 
Palestinian suicide bombers used moral justification and dehuminisation to moralise their violence as serving an altruistic cause of freedom from an oppressive and dangerous threat ${ }^{25}$. Aly's analysis of the narratives employed on Islamist extremist websites acknowledges that biographical narratives of suicide bombers on such websites adhere to a strict format that portray the suicide bomber as a devout martyr motivated to self- sacrifice by absolute submission to faith and an intense desire to fulfil the greatest demonstration of piety possible. Extremist narratives also displace the responsibility for violence on the victims of terrorist acts claiming that atrocities perpetrated against Muslims by Western regimes are the primary cause for their retaliatory actions ${ }^{26}$. The claims made in extremist narratives empower individuals to absolve themselves of blame for inhumane acts and behaviours while religion provides a moral template for justifying acts of violence as a moral response to perceived injustice.

Considering the application of moral disengagement to radicalising influences, it is pertinent to also examine if social-cognitive mechanisms of moral disengagement can also be applied to the development of preventative measures. In this respect, the literature is lacking with no studies examining how processes of moral disengagement may make individuals more vulnerable to violent extremist influences or, importantly, how preventative interventions may enhance personal resilience to radicalising influences by activating self- sanctioning mechanisms.

Moral disengagement appears as a personal risk factor to engaging in violent extremism and methods of measuring moral disengagement processes have been used to predict acts of violence among young people and support for violent extremism ${ }^{27}$. Conversely, process of moral disengagement may be adapted and moderated to reinforce self -regulatory systems that prevent individuals from being influenced by violent extremism. McAlister notes that education and persuasive peer modelling has been shown to psychologically immunise young people against the social influences that promote negative behaviours such as smoking and racism. He suggests that similar methods may be useful in developing young people's resistance to influences of moral disengagement ${ }^{28}$.

In the next section of this article, the authors describe the Beyond Bali school based education program for countering violent extremism. Beyond Bali uses a multi- modal approach combining cognitive behavioural and knowledge based elements to modulate moral disengagement mechanisms (prevent) and reinforce self -regulatory mechanisms (resilience) to counter violent extremism.

\section{Beyond Bali: An Education Resource for Teachers and Students to Build Resilience to Violent Extremism}

The Bali Bombing in October 2002 was arguably the most devastating peace time attack in the Australasian region. At approximately $11 \mathrm{pm}$ a person borne improvised explosive device (IED) was detonated inside the popular Paddy's Pub in central Kuta, Bali's bustling nightclub district. The first explosion sent patrons, confused and injured, into the streets and towards the shelter of the nearly Sari Club. Minutes later, a vehicle borne IED was detonated from a van parked just outside the Sari Club causing the total destruction the club and its surrounds and most of the 202 casualties. The Bali Bombing was particularly significant for Australians, not only because 88 of the 202 dead were Australian but also because Australians have for decades dominated tourism in Bali making up around $25 \%$ of overall tourist arrivals to the Island. In Australia, the bombings were framed as a 
direct attack on Australia and particularly on Australian values. The media and political discourse on the attacks emphasised the perception that Jemaah Islamiyah (who claimed responsibility for the attacks) targeted Kuta in protest to Bali's indulgence of Western decadence. ${ }^{29}$

Occurring just one year and one day after the September 11 attacks on the United States, the Bali Bombings further consolidated an already developing discourse that constructed Salafi Jihadi terrorism as an assault on Western values of democracy, freedom and liberty. Australia's response to September 11, the Bali Bombings and subsequent international Salafi Jihadi terrorist attacks was to reaffirm its commitment to the values of democracy that the attackers were seen to be targeting. As a consequence, the policy response in Australia reflects a focus on promoting civic engagement and democratic participation by groups that are seen to be at risk or vulnerable to the radicalising forces of Al Qaeda influenced ideology. ${ }^{30}$ Education programs developed in response to the terrorist threat in Australia have largely targeted Muslim communities and consist primarily of leadership and mentoring programs, interfaith education and programs that promote social values of respect, understanding and tolerance. The range of programs developed and driven by the Australian policy response to terrorism reflect an understanding of vulnerability as an individual and collective phenomenon triggered by social isolation and resilience as the individual and collective engagement in democratic participation, social harmony and interfaith tolerance. While some programs were school based, most were community based and targeted a specific ethnic (Arab, Somali, African, Lebanese) or religious group (Muslim). ${ }^{31}$ As stated earlier in this paper, this focus reflects some of the problematic of the broader policy approach to preventing violent extremism that has been articulated in scholarly analysis and evaluations of 'soft' counter terrorism strategies. There is however some suggestion that awareness and tolerance of other religious and ethnic groups is a resilience factor to violent extremism, though the evidence supporting this assertion is scant. ${ }^{32}$

Among the range of interventions to counter violent extremism in Australia, there was no school based program that a) did not specifically target a singular religious or ethnic group; b) focussed exclusively on countering violent extremism; c) could be integrated into the Australian school curriculum; and d) constructed an understanding of individual resilience as the capacity to psychologically resist the moral disengagement mechanisms embedded in violent extremist narratives. In addition, attempts to integrate the teaching of terrorism in schools as a platform for developing students' awareness and capacity to critically analyse acts of violence had met with public resistance and ethical and methodological challenges. In this context, the Beyond Bali Education program was conceived as a project that would translate theoretical models of moral disengagement and conceptual understandings of resilience to a practical program that could, potentially, provide evidence for the development of future programs in the countering violent extremism space.

The Beyond Bali Education Program was developed through collaboration between the Bali Peace Park Association Incorporated (BPPAI) and Curtin University, Western Australia. BPPAI is a nonprofit organisation formed by survivors, families and friends of the 2002 and 2005 Bali bombings with the mission of creating a peace park on the Sari Club site of the 2002 Bali terrorist attacks in Kuta. Development of the resource was guided by an advisory body that consisted of the project leader, Anne Aly, a representative from the BPPAI, a Muslim youth representative, school teachers from two local schools and the project team, Elisabeth Taylor and Saul Karnovsky who developed the resource. 
The project was born out of a research interest in citizen driven responses to terrorism that explores the performative capacity of such initiatives to construct alternative and counter narratives to terrorism. As part of this, Anne Aly, is currently the Chief Investigator on a three year research project that explores how the Bali Peace Park initiative represents a form of citizen driven performative resistance to terrorism through the construction of contested discourses that take place and are performed in and around the site of terrorist attacks. ${ }^{33}$

Moral disengagement theory provided a conceptual framework for identifying elements in the program that could potentially counter the violent extremist narrative thereby building resilience to the psychological influence of these narratives. Moral development theory offered a pedagogical approach to developing ethical discourse through the use of moral dilemma stories. Together, these two approaches, if implemented effectively, can be used to construct education interventions for violent extremism that target mechanisms of moral disengagement and facilitate the development of moral learning.

The use of dilemma stories in moral education can be traced back to Kohlberg who pioneered a cognitive-developmental theory of moral development ${ }^{34}$. Dilemma stories are often suggested as a pedagogical approach to developing ethical discourse and critical reflection in the classroom.

According to Kohlberg's theory, dilemma stories are grounded in the concept of values clarification, through which students explore their own values and compare and discuss them with their peers ${ }^{35}$. This type of approach can result in transformative learning whereby individuals can critically assess their own beliefs and values and reconstruct their assumptions and perspective leading to the active construction of new values and moral learning ${ }^{36}$.

The theoretical premises were:

1. Individuals who engage with a violent extremist narrative are more likely to become radicalised towards violent extremism as they adopt moral disengagement mechanisms and disengage their self- sanctions to:

- $\quad$ Reconstruct violent extremism as morally just

- $\quad$ Dehumanise victims

- $\quad$ Obscure personal agency

- Disregard the harmful or negative consequences of violent extremism

2. Education interventions can psychologically immunise young people against the social influences that promote violent extremism by engaging their self- sanctions to:

- Construct violent extremism as morally unjust and inhumane

- Empathise with victims of violent extremism

- $\quad$ Develop self- efficacy

- $\quad$ Regard the harmful or negative effects of violent extremism 
3. Educating students on the social impacts of the Bali bombings provides them with an opportunity to humanise the victims of violent extremism and assess the harmful impacts of violent extremism in ways that challenge violent extremism.

4. Dilemma stories around the Bali bombings events facilitate moral learning by allowing students to explore and compare their own values and reconstruct their assumptions and perspective.

5. The Bali Peace Park provides them with a concrete example of how societies can respond to violent extremism in positive and productive ways and encourages them to think about ways in which they can also resist extremism both individually and as a collective.

On the basis of these five theoretical assumptions and research on good practice in education interventions, each module of Beyond Bali used cognitive behavioural and knowledge based approaches to build social resilience to violent extremism by:

- $\quad$ providing students with the skills and tools to critically analyse and challenge violent extremism, its causes and consequences;

- $\quad$ raising awareness and education on the social impacts of violent extremism;

- encouraging students to think about how societies can resist the influence of violent extremism; and

- $\quad$ engaging students through activities and discussion about the Bali Peace Park as a response to violent extremism.

Module 1 of the program is designed to engage students in the context of Beyond Bali. While Bali is enjoyed as a favourite holiday destination for many Australians (particularly in Western Australia), popular understanding of Australia's connection to Bali is largely based only on the experiences of tourism. Developing students' knowledge and understanding of the cultural and historical connections between Australia and Bali is designed to engage their interest and contextualise the program.

Module 2 also takes a combined knowledge based and cognitive behavioural approach by educating students about the consequences of violent extremism and building empathy. Students learn about the devastating consequences of the Bali Bombings through eyewitness accounts of a Bali Bombing survivor. Approaching the subject matter in this way allows students to self- reflect on their moral values and reinforce those values that empathise with victims, construct violent extremism as morally unjust and regard the harmful impacts of violent extremism. At this stage of the program, students have been presented with the problem. As they proceed through the program they will be required to use moral reasoning and problem solving in further consideration of violent extremism and its consequences.

Module 3 is based on ethical dilemma story pedagogy that promotes critical thinking and reflection as well as individual and collaborative decision-making. Dilemma stories are typically based on ethical dilemma situations. Dilemma stories engage students in a moral dilemma situation in which choices have to be made at different stages of the story. Students are invited to identify with the character in the story that is faced with the dilemma and reflect on how the problem can be solved. 
They then exchange their own approaches and views with their peers in a whole-class discussion ${ }^{37}$. The focus is not so much on moral reasoning but rather on deep engagement with one's personal values and a confrontation with other people's values which might be different from one's own. At this stage of the program students are developing self-efficacy and exploring ways in which they can or would respond to violent extremism. Students verbalise and discuss their values and reinforce those values that self-sanction against violence.

Module 4 provides students with knowledge of peace parks as a positive response to violent extremism and conflict. Students are engaged in concrete examples of peaceful resolutions to violence and conflict and reflect on their own capacity to respond to adverse problems through positive activities such as peace activism.

The final module of Beyond Bali, engages students in a creative exercise designed to activate their self-efficacy. Schools are encouraged to take a collaborative approach to building a peace park or garden consulting with the school community and involving parents, staff and local communities or partnering with other schools.

\section{Description of the program}

The five modules of Beyond Bali guide students progressively through five stages of engagement, empathy, moral reasoning and mindfulness, problem solving and creative resolution using the context of the Bali bombings and the Bali peace park. The program systematically works through a series of activities to engage students with the social impacts of the Bali terrorist attacks and guide them through peaceful alternatives to violence.

Each module in the program links to the Australian Curriculum and consists of a series of activities that meet the learning outcomes subscribed in the Australian Curriculum Framework. Teachers may elect to do all or some of the activities with their students as they work through the program.

Table 1: Beyond Bali Program Description

\begin{tabular}{|l|l|l|}
\hline Phase & Description of Activities & Approach \\
\hline $\begin{array}{l}\text { Module 1 } \\
\text { The Australia - Bali } \\
\text { introduction to our } \\
\text { shared history }\end{array}$ & $\begin{array}{l}\text { Module } 1 \text { begins with an in depth study of the } \\
\text { island of Bali - its geography, history and } \\
\text { culture. Background to Australia's geographic } \\
\text { and cultural connection with the island is } \\
\text { interwoven throughout the activities in order } \\
\text { to provide the necessary context for studying } \\
\text { the Bali bombings. Students engage with a } \\
\text { variety of material (pictorial, text \& video) in a } \\
\text { collaborative manner to arrive at a } \\
\text { comprehensive and holistic understanding of } \\
\text { the content. }\end{array}$ & $\begin{array}{l}\text { Cognitive Behavioural and } \\
\text { knowledge based }\end{array}$ \\
\hline $\begin{array}{l}\text { Module 2 } \\
\text { Peace and conflict in } \\
\text { Bali and the world: } \\
\text { Understanding } \\
\text { terrorism through } \\
\text { our experiences with }\end{array}$ & $\begin{array}{l}\text { Module 2 begins with an exploration of the } \\
\text { events surrounding the bombings, which is } \\
\text { facilitated through eyewitness accounts } \\
\text { bringing a personal and relevant perspective to } \\
\text { the events. It is essential here to convey an } \\
\text { understanding of the sensitive and emotional }\end{array}$ & $\begin{array}{l}\text { Knowledge based } \\
\text { developing empathy }\end{array}$ \\
\hline
\end{tabular}




\begin{tabular}{|c|c|c|}
\hline $\begin{array}{l}\text { recent terrorist } \\
\text { actions }\end{array}$ & $\begin{array}{l}\text { nature of these events to all participants - with } \\
\text { particular focus on the damage done to } \\
\text { individuals, families and communities. The } \\
\text { significant and far reaching social and } \\
\text { economic impacts to Australia and Bali of the } \\
\text { terrorist actions are also presented in this } \\
\text { module. The ideas of peace and conflict are } \\
\text { then presented through examples, which } \\
\text { participants are then encouraged to } \\
\text { contextualise to their own experiences. The } \\
\text { module then moves on to an exploration of the } \\
\text { notion that terrorism aims to cause division } \\
\text { and conflict. Module } 2 \text { will finally prompt } \\
\text { students to discover the notion that when we } \\
\text { engage with peace individuals and } \\
\text { communities are able to build empathy for } \\
\text { others. This empathy can then offer us } \\
\text { resilience against the division and conflict that } \\
\text { results from the actions of terrorist groups. }\end{array}$ & \\
\hline $\begin{array}{l}\text { Module } 3 \\
\text { These are Moral } \\
\text { dilemmas: Making } \\
\text { 'good' decisions }\end{array}$ & $\begin{array}{l}\text { Module } 3 \text { presents a dilemma story which } \\
\text { contains a series of moral dilemmas for } \\
\text { participants to engage with. Each situation is } \\
\text { designed to allow an individual to question or } \\
\text { express their values in a safe, supportive and } \\
\text { intellectually healthy environment. Resulting } \\
\text { from these enquires emphasis is then given } \\
\text { over to fostering a democratic approach in } \\
\text { formulating productive strategies for resolving } \\
\text { conflicts and making good decisions. The } \\
\text { Module's impact is enhanced by using real life } \\
\text { examples of survivors and their families. }\end{array}$ & $\begin{array}{l}\text { Critical constructivist; } \\
\text { content-based; } \\
\text { ethical dilemma story } \\
\text { pedagogy; } \\
\text { promotes critical thinking } \\
\text { and critical reflection; } \\
\text { individual and collaborative } \\
\text { decision-making }\end{array}$ \\
\hline $\begin{array}{l}\text { Module } 4 \\
\text { The Bali Peace Park } \\
\text { in context }\end{array}$ & $\begin{array}{l}\text { Module } 4 \text { presents several existing peace parks } \\
\text { situated across the globe with focus on the } \\
\text { special characteristics and functions of peace } \\
\text { parks. The module commences with an } \\
\text { introduction to the concept of peace parks } \\
\text { followed up by a web quest which takes groups } \\
\text { of students to various parts of the world and } \\
\text { allows them to investigate the characteristics } \\
\text { of 'their' peace parks. Students not only } \\
\text { enhance their knowledge of peace parks but } \\
\text { also their IT- and investigation skills. }\end{array}$ & $\begin{array}{l}\text { Knowledge based } \\
\text { Cognitive Behavioural }\end{array}$ \\
\hline $\begin{array}{l}\text { Module } 5 \\
\text { Thoughts into } \\
\text { action: Creating your } \\
\text { own Peace Park }\end{array}$ & $\begin{array}{l}\text { Module } 5 \text { allows for a revision on what has } \\
\text { been learnt to far as the activities rely on the } \\
\text { extensive scaffolding that has occurred in the } \\
\text { preceding modules. Participants will need to be } \\
\text { guided by their particular school site } \\
\text { requirements, resourcing and time } \\
\text { availabilities. Initially research should be }\end{array}$ & Cognitive Behavioural \\
\hline
\end{tabular}




\begin{tabular}{|l|l|l|}
\hline & $\begin{array}{l}\text { conducted and it is recommended that a } \\
\text { consulting process occur with the } \\
\text { administration team. The focus for the module } \\
\text { is an authentic learning experience where by } \\
\text { the learning of the previous modules can be } \\
\text { applied in the design and creation of a school } \\
\text { site peace space, garden or model. In groups } \\
\text { participants should look at the needs of the } \\
\text { school community and plan out the project } \\
\text { with all the necessary requirements given due } \\
\text { consideration. This module allows for multiple } \\
\text { connections to be made with other students } \\
\text { and parents as well as community and school } \\
\text { leaders. }\end{array}$ & \\
\hline
\end{tabular}

\section{Program Evaluation}

Beyond Bali was trialled in September and October 2012 with students at two metropolitan schools in the Perth region- one a public school and the other an Islamic community school. The public school incorporated the program into its curriculum with a group of students in the gifted and talented program (aged 15 and 16). The Islamic community school chose to trial some modules of Beyond Bali with year 9 students (average age 14).

The program was evaluated for its effectiveness as a teaching and learning tool for building resilience to violent extremism. This involved administering a short questionnaire for teachers and students involved in the trial program. The Project Team assessed whether the package is an effective education medium for promoting moral engagement with the social impacts of violent extremism and other effective measures such as usability of the package, interest in the activities and usefulness against learning outcomes. The project team also held discussions with teachers and students to gain an insight into their experiences in using the Beyond Bali program.

Students who participated in the trial of Beyond Bali felt that the program was worthwhile and relevant because the content was closely connected to subjects they were already studying as part of their school curriculum. Successful school based programs rely on school staff buy-in and engaging students in meaningful ways ${ }^{38}$. Aligning the program to the national school curriculum, rather than presenting it as a stand- alone program, ensured that both teachers and students would engage with its content.

Some students expressed that they felt the program was worthwhile because it covered religious extremism, the motives of the terrorists and allowed them to explore their own values and develop skills to differentiate between extremists and the general Muslim population. Good practice in knowledge based initiatives suggests that such initiatives, when used in preventing support for violent extremism, work best when they are encourage participants to question and challenge their own thinking. Conventional approaches that passively involve participants in learning about other religions, cultures or societies were found to be ineffective because they do not allow for selfreflection ${ }^{39}$. 
Students pointed out that using the story of a Bali Bombing survivor in the program content was very powerful and allowed them to put a personal, more human face to the tragedy of terrorism. This finding indicates that the program had some success (though this success was not measured in quantitative terms) in engaging the participants' self-sanctions to empathise with victims of violent extremism. De-humanising of victims is one mechanism of moral disengagement as is disregard for the harmful consequences of violence. The approach of educating students about the negative impacts of violent extremism through the story of a Bali Bombing survivor may develop psychological resilience to violent extremism.

The most interesting aspects of the program according to the participants were the interactive lessons and group discussions that allowed reflect on their moral values in a safe and supportive environment. An evaluation of good design in education interventions found that effective interventions incorporated activities that were enjoyable and interesting. It is recommended that intervention programs accommodate youth's interests as well as their development needs ${ }^{40}$. Many of the activities in Beyond Bali were developed with an awareness of the need to engage the participants in activities that they would find exciting and interesting. This proved to be an effective approach for engaging the students in a subject matter that is sensitive and can be provocative. Students comment that they found the program interesting and effective because it provided them with a way to talk about, think about and explore violent extremism they could engage with.

The following excerpts are taken from student written feedback and comments on the Beyond Bali program. They demonstrate some of the perspectives of student participants in the program. These excerpts are by no means a measure of the success or otherwise of the program. They do however highlight ways in which the program impacted positively on the participants:

"This course has begun to teach principles that are very relatable about tolerance, forgiveness and finding out other people's perspectives. It has really put it in a whole new light as it [Bali bombing] was something that happened to us not just as individuals but as Australian people and we all experienced it together"

"This gave us an opportunity to discuss the motivations behind it [Bali Bombing] and in a way it is really important because it will give us, the next generation who are people who are going to in parliament and running the world the opportunity to what motivates them and what we can change, it's about finding solutions to these problems."

"I knew there was a bombing and it was a bad thing that happened but just the way people talked about it I assumed that the people responsible were 100\% fruit loop and it just a random act and was a tragedy but we should just move on, not that something could be learned from it."

"It [Bali bombings] was really disconnected to us until we learned this module, not something we thought about and connected to everyday life."

"It really made it less of a headline and more of an act of different perspectives, we may have physically heard of it but we did not know about the effects, how many Australians were effected and basically we did not know how it may of effected just people in our community, people we may know and it really just puts into perspective the community influence it can have." 
As Beyond Bali has gained momentum, information about the program has extended beyond schools. Beyond Bali is currently being distributed to around 400 high schools across Australia and is available for download from the Bali Peace Park Association website. It will also be available for download from other organisation and government websites. In addition to student feedback, Beyond Bali has also been recognised by terrorism victim and survivor groups who have been particularly encouraged by the programs use of a survivor's story to educate students on the events of the Bali Bombings. Victim's groups see this aspect of the program as a way to give a voice to victims of terrorism and humanise those lost to terrorist acts. This particular outcome of the project has significance for the ongoing research into victim initiated responses to terrorism that, often in opposition and resistance to official discourses on terrorism and counter terrorism, act in ways that attempt to humanise victims (through commemoration and remembrance as well as initiatives such as the Bali Peace Park). The various attempts to humanise victims of terrorism, mostly by survivors and families, can be further explored for their capacity to develop and sustain effective counter narratives to violent extremism. Central to this analysis of victim driven responses is an understanding of how terroristic narratives integrate moral disengagement mechanisms that dehumanise victims and disregard the injurious consequences of violent action and conversely, how victim driven responses can counter these elements through their own narratives.

\section{Conclusion}

Preventative approaches in national counter terrorism strategies stress the importance of programs to counter violent extremism by building resilience to violent extremism. These approaches have come under criticism for the emergence of programs that assume that communities and individuals are particularly vulnerable to violent extremism by virtue of their religious or ideological beliefs. Prevent and resilience programs appear to be rarely based on sound theoretical understanding of risk and resilience and there is limited empirical evidence on risk and resilience factors for violent extremism. Within the literature that does exist, the theory of moral disengagement offers a conceptual approach to developing education based prevention strategies.

Moral disengagement is a psychological process through which individuals that are normally socialised commit acts of violence in violation of their moral standards. The process involves mechanisms through which the individual moralises violence as a just action, dehumanises the victims of violence, obscure their personal agency and disregard the harmful consequences of violent behaviours.

Moral disengagement theory has been applied to analyses of violent extremism and support for terrorism but has not been utilised as a theoretical framework for the development of education interventions for building resilience to violent extremism. The Beyond Bali Education Program is a five module program about the 2002 Bali Bombing, its impact and the Bali Peace Park response that is designed to build psychological resilience to violent extremism. The program applied a theoretical framework based on Moral Disengagement and Moral Development to engage students in learning about the Bali bombings and exploring their own values and assumptions. The program is designed to activate students' self-regulatory mechanisms of moral agency and psychologically immunise them against the social influences that promote violent extremism. A qualitative evaluation of the program trial indicates that the program achieved some success in building resilience by engaging participants in constructing violent extremism as unjust and inhumane; creating empathy with 
victims of violent extremism; developing self-efficacy in resisting violent extremism influences and responding to influences in positive, productive ways and considering the devastating impacts of violent extremism. 


\footnotetext{
${ }^{1}$ Beyond Bali was funded by the Australian Governments' Building Community Resilience Grants of the Federal Attorney General's Department.

2 Bethany Hiatte. "School terror lessons to kill Australians." The West Australian, 25 August 2010.

${ }^{3}$ Stevan Weine and Osman Ahmed. "Building Resilience to Violent Extremism among Somali-Americans in Minneapolis- St. Paul. Final Report to Human Factors/Behavioural Sciences Division, Science and Technology Directorate, U.S Department of Homeland Security." Maryland, 2012, 1

${ }^{4}$ HM Government, "Prevent Strategy." edited by Secretary of State for the Home Department. London: HM Government, 2011.

${ }^{5}$ Malin Grundel and Mieke Maliepaard. "Knowing, Understanding and Practising Democratic Citizenship: An Investigation of the Role of Religion among Muslim, Christian and Non-Religious Adolescents." Ethnic and Racial Studies (2011): 1-22.
}

${ }^{6}$ Shalhevet Attar-Schwartz and Asher Ben-Arieh. "Political Knowledge, Attitudes and Values among Palestinian and Jewish Youth in Israel: The Role of Nationality, Gender and Religiosity." Children and Youth Services Review 34, no. 4 (2012): 704-12.

${ }^{7}$ Ellen Quintelier, "The Political Participation of Immigrant Youth in Belgium." Journal of Ethnic and Migration Studies 35, no. 6 (2009): 919-37.

${ }^{8}$ Anne Aly, "Australian Muslims Responses to the Media Discourse on Terrorism: Pursuing Public Spheres in a Secular State.". Australian Journal of Social Issues 42, no. 1 (2007): 27-40.

${ }^{9}$ Ben O'Loughlin and Marie Gillespie. "Dissenting Citizenship? Young People and Political Participation in the Media-Security Nexus 1." Parliamentary Affairs 65, no. 1 (2012): 115-37.

${ }^{10}$ Communities and Local Government Committee, "Preventing Violent Extremism: Sixth Report of Session 2009-2010." London: House of Commons, 2010.

${ }^{11}$ David Stevens, "In Extremis : A Self-Defeating Element in the 'Preventing Violent Extremism' Strategy." Political Quarterly 80, no. 4 (2009): 517-25.

${ }^{12}$ A Bandura, "Selective Moral Disengagement in the Exercise of Moral Agency." Journal of Moral Education 31, no. 2 (2002): 101-19.

${ }^{13}$ Trees Pels and Doret J de Ruyter. "The Influence of Education and Socialization on Radicalization: An Exploration of Theoretical Presumptions and Empirical Research." Journal of Research and Practice in Children's Services 41, no. 3 (2012): 311-25, 323.

${ }^{14}$ Christopher Boucek, "Saudia Arabia's "Soft" Counterterrorism Strategy: Prevention, Rehabilitation and Aftercare." In Carnegie Papers Middle East Program: Carnegie Endowment for International Peace, 2008.

${ }^{15}$ S Sanah Sheikh, Shama Sarwar, and Chris Reed. "Teaching Methods That Help Buld Resilience to Extremism Rapid Evidence Assessment." edited by Department for Education. London: Department for Education 2010.

${ }^{16}$ Mary Karapetian Alvord and Judy Johnson Grados. "Enhancing Resilience in Children." Professional Psychology: Research and Practice 36, no. 3 (2005): 238-45.

17 Thomas J Dishion and Arin Connell. "Adolescents' Resilience as a Self-Regulatory Process.(Author Abstract)." Annals of the New York Academy of Sciences 1094 (2006): 125.

${ }^{18}$ Nathaniel Laor, Leo Wolmer, Moshe Alon, Joanna Siev, Samuel Eliahu, Paz Toren, "Risk and Protective Factors Mediating Psychological Symptoms and Ideological Commitment of Adolescents Facing Continuous Terrorism." Journal of Nervous \& Mental Disease: 194, no. 4 (April 2006): 279-86

${ }^{19}$ Stevan Weine and Osman Ahmed. "Building Resilience to Violent Extremism among Somali-Americans in Minneapolis- St. Paul. Final Report to Human Factors/Behavioural Sciences Division, Science and Technology Directorate, U.S Department of Homeland Security." Maryland, 2012, 1

${ }^{20}$ Tony Munton, Alison Martin, Theo Lorenc, Isaac Marrero-Guillamon, Farah Jamal, Angela Lehmann, Chris Cooper, and Matthew Sexton. "Understanding Vulnerability and Resilience in Individuals to the Influence of Al Qa'ida Violent Extremism. A Rapid Evidence Assessment to Inform Policy and Practice in Preventing Violent Extremism." edited by Office for Security and Counter-Terrorism. London: Home Office, 2011.

${ }^{21}$ Ibid

${ }^{22}$ A. Bandura, "Moral Disengagement in the Perpetration of Inhumanities." Personality and Social Psychology Review 3, no. 3 (1999): 193- 209. 
${ }^{23}$ A. Bandura, "Mechanisms of Moral Disengagement in Terrorism." In Origins of Terrorism: Psychologies, Ideologies, Theologies, States of Mind, edited by W Reich. 161-91. Cambridge: Cambridge University Press, 1990.

${ }^{24}$ Ibid, 164

${ }^{25}$ M Hafez, "Moral Agents, Immoral Violence: Mechanisms of Moral Disengagement in Palestinian Suicide Terrorism." In Tangled Roots: Social and Psychological Factors in the Origins of Terrorism edited by J Victoroff. 292-307: IOS Press, 2006.

${ }^{26}$ Anne Aly, "The Terrorists' Audience: A Model of Internet Radicalisation." Journal of Australian Professional Intelligence Officers 17, no. 1 (2009): 3-19.

${ }^{27}$ See for example Alfred L McAlister, "Moral Disengagement: Measurement and Modification ". Journal of Peace Research 38, no. 1 (2001): 87 -99; Paul S Lieber, Yael Efreom- Lieber, and Christopher Rate. "Moral Disengagement: Exploring Support Mechanisms for Violent Extremism among Young Egyptian Males." Paper presented at the Proceedings of the 1st Australian Counter Terrorism Conference Perth, 2010.

${ }^{28}$ McAlister

${ }^{29}$ For a comprehensive discussion on the discursive response to terrorism in Australia see Anne Aly. "A study of audience responses to the media discourse about the 'Other': the fear of terrorism between Australian Muslims and the broader community." Lampeter: Edwin Mellen Press, 2010.

${ }^{30}$ Anne Aly, "The Policy Response to Home-Grown Terrorism: Reconceptualising Prevent and Resilience as Collective Resistance." Journal of Policing, Intelligence and Counterterrorism 8, no. 1 (2013): 2-18

${ }^{31}$ This information is drawn from a rapid evidence assessment and analysis of Australia's counter terrorism and countering violent extremism programs 2003- 2012. This includes community based programs funded under the Building Community Resilience Grants Program under the auspices of the Federal Countering Violent Extremism Unit within the Department of the Attorney General.

${ }^{32}$ Munton et al

${ }^{33}$ The research project mentioned here titled "Collective action and resistance to terrorism: Constructions of the Bali Peace Park as counter-terrorism" is funded by an Australian Research Council Discovery Early Career Researcher Grant 2013-2016.

${ }^{34}$ L. Kohlberg, Essays on Moral Development: The Psychology of Moral Development. The Nature and Validity of Moral Stages. . San Francisco: Harper and Row, 1984.

${ }^{35}$ Elisabeth Settelmaier, "Mapping an Interpretive Researcher's Sensitivities toward Her Subject(S): A Critical Autobiography." In, Proceedings Western Australian Institute for Educational Research Forum (2003).

${ }^{36}$ Elisabeth Settelmaier, "Dilemma Stories as a Way of Addressing Ethical Issues in the Context of Science Education. ." In Western Australian Institue for Educational Research. Edith Cowan University, Mt. Lawley, Perth, WA, 2002.

${ }^{37}$ Settelmaier 2003

${ }^{38}$ Sheikh et al

${ }^{39}$ Ibid

${ }^{40} \mathrm{Ibid}$ 